\title{
HOW DO PSYCHOLOGICAL, NUTRITIONAL FACTORS, AND AMBIENT SMOKE EXPOSURE, AFFECT THE RISK OF LOW BIRTH WEIGHT?: A PATH ANALYSIS EVIDENCE
}

\author{
Isne Susanti'), Harsono Salimo²), Yulia Lanti Retno Dewi3) \\ 1)Masters Program in Public Health, Universitas Sebelas Maret \\ 2)Department of Pediatrics, Dr. Moewardi Hospital, Surakarta \\ 3)Department of Nutrition, Faculty of Medicine, Universitas Sebelas Maret
}

\begin{abstract}
Background: Nearly half of the world's population rely on solid fuels (wood or coal) for their everyday household energy needs. Much of this fuel is burned in open fires and simple stoves with inadequate ventilation, causing very high levels of smoke exposure, particularly for women and infants. This study aimed to investigate the associations between psychological, nutritional factors, and ambient smoke exposure, affect the risk of low birth weight.

Subjects and Method: A case control study was carried out at 25 community health centers in Gunungkidul, Yogyaarta, Indonesia, from January to February 2020. A sample of 200 infants was selected by simple random sampling. The dependent variable was low birth weight. The ondependent variables were maternal education, early marriage, family income, maternal age at pregnancy, ambient smoke exposure, gestational stress, anemia, and maternal mid-upper arm circumference (MUAC). The data were obtained from medical record, maternal and child health book, and questionnaire. The data were analzed by path analysis.

Results: The risk of low birth weight was directly increased with maternal age $<20$ or $\geq 35$ years $(b=1.7 ; 95 \% \mathrm{CI}=0.62$ to $2.9 ; \mathrm{p}=0.002)$, anemia $(b=2.7 ; 95 \% \mathrm{CI}=1.77$ to 3.67 ; $\mathrm{p}<0.001)$, gestational stress $(\mathrm{b}=1.7 ; 95 \% \mathrm{CI}=0.41$ to $2.99 ; \mathrm{p}=0.009)$, and ambient smoke exposure ( $b=1.6 ; 95 \% \mathrm{CI}=0.62$ to $2.72 ; \mathrm{p}=0.002$ ). The risk of low birth weigth was indirectly decreased with early marriage, maternal education, maternal MUAC, and family income.

Conclusion: The risk of low birth weight is directly increased with maternal age $<20$ or $\geq 35$ years, anemia, gestational stress, and ambient smoke exposure. The risk of low birth weigth is indirectly decreased with early marriage, maternal education, maternal MUAC, and family income.
\end{abstract}

Keywords: low birth weight, early marriage, gestational stress, path analysis

\section{Correspondence:}

Isne Susanti. Masters Program in Public Health, Universitas Sebelas Maret. Jl. Ir. Sutarni 36A, Surakarta 57126, Central Java. Email: isnesusanti@gmail.com. Mobile: +6285271128121 .

The $7^{\text {th }}$ International Conference on Public Health

Solo, Indonesia, November 18-19, 2020 | 94

https://doi.org/10.26911/the7thicph.01.49 